Tectonics

\title{
First results of the CRLN seismic network in the western Corinth Rift: evidence for old-fault reactivation
}

\author{
Hélène Lyon-Caen ${ }^{\mathrm{a}, *}$, Panayotis Papadimitriou ${ }^{\mathrm{b}}$, Anne Deschamps ${ }^{\mathrm{c}}$, Pascal Bernard ${ }^{\mathrm{d}}$, \\ Kostas Makropoulos ${ }^{b}$, Francesco Pacchiani ${ }^{\text {a }}$, Geneviève Patau ${ }^{\mathrm{d}}$ \\ a Laboratoire de géologie, École normale supérieure, 24, rue Lhomond, 75252 Paris cedex 05, France \\ ${ }^{\mathrm{b}}$ Department of Geophysics, University of Athens, Panepistimioupoli, Zografou, 15784, Greece \\ ${ }^{\mathrm{c}}$ UMR Géosciences Azur, CNRS/UNSA250, rue Albert-Einstein, 06560 Valbonne, France \\ ${ }^{\mathrm{d}}$ Laboratoire de sismologie, Institut de physique du Globe de Paris, 4, place Jussieu, 75252 Paris cedex 05, France
}

Received 17 November 2003; accepted after revision 1 December 2003

Written on invitation of the Editorial Board

\begin{abstract}
The 12 stations Corinth Rift Laboratory Seismological Network (CRLNET) aims at monitoring the seismicity $(M l>1)$ in the CRL area and at constraining the geometry of active structures at depth. Two years of microseismicity (2000-2001) recorded by the CRLNET in the Aigion area shows: (1) background seismicity inside the Corinth rift at depth of 4.5-11 km, deepening towards the north and no activity in the upper $4 \mathrm{~km}$ of the crust - this seismicity is not clearly related to major faults observed at the surface -; (2) a swarm, $6 \mathrm{~km}$ south of the city of Aigion, associated with the $M w=4.2,8$ April 2001 earthquake. This earthquake occurred at $6 \mathrm{~km}$ depth, on a SW-NE oriented fault dipping $40^{\circ}$ to the northwest and corresponds to normal faulting with a right lateral component of slip. It likely occurred on an old structure reactivated in the present stress field. To cite this article: H. Lyon-Caen et al., C. R. Geoscience 336 (2004).
\end{abstract}

(c) 2003 Académie des sciences. Published by Elsevier SAS. All rights reserved.

\section{Résumé}

Premiers résultats du réseau sismique (CRLN) de la partie ouest du rift de Corinthe : évidence de la réactivation d'une ancienne faille. Le réseau de 12 stations sismologiques installées dans la région du Corinth Rift Laboratory (CRL) permet de localiser la microsismicité $(M l>1)$ de cette zone depuis avril 2000, avec une précision de l'ordre du kilomètre afin, en particulier, de contraindre la géométrie des structures actives en profondeur. La microsismicité enregistrée correspond à une sismicité de fond sous le golfe de Corinthe entre 4,5 et $11 \mathrm{~km}$ de profondeur, à laquelle se superpose une activité en essaims. Les quatre premiers kilomètres de la croûte sont asismiques. La sismicité s'approfondit vers le nord et n'est pas directement associée aux failles actives observées en surface. Le séisme du 8 avril $2001(M w=4,2)$ s'est produit à $6 \mathrm{~km}$ de profondeur. L'étude du mécanisme au foyer et des répliques indique qu'il s'est produit sur un plan de faille orienté SW-NE, plongeant vers le nord-ouest à $40^{\circ}$. C'est un séisme en faille normale avec une composante décrochante dextre, qui s'est probablement produit sur une ancienne structure réactivée dans le champ de contrainte actuel (extension $\sim$ N10 $0^{\circ}$ ) et qui n'émerge pas en surface. Pour citer cet article: H. Lyon-Caen et al., C. R. Geoscience 336 (2004).

(c) 2003 Académie des sciences. Published by Elsevier SAS. All rights reserved.

\footnotetext{
* Corresponding author.

E-mail address: Helene.Lyon-Caen@ens.fr (H. Lyon-Caen)
} 
Keywords: Corinth Rift; seismicity; extension; active faults

Mots-clés : rift de Corinthe ; extension ; sismicité ; failles actives

\section{Version française abrégée}

Un réseau de 12 stations sismologiques (CRLN) a été installé en avril 2000 dans la zone d'étude du Corinth Rift Laboratory (CRL), afin de contraindre la géométrie des failles en profondeur dans cette région où l'activité sismique est importante et le taux de déformation élevé. Le réseau, équipé de sismomètres $2 \mathrm{~Hz}$ dont une partie est installée dans des forages de 60-100 m, enregistre en continu à $125 \mathrm{~Hz}$ et localise les événements de magnitude supérieure à 1 . D'avril 2000 à décembre 2001, la sismicité enregistrée est importante (plus de 2000 événements localisés dans le réseau, avec une précision standard de l'ordre de $1 \mathrm{~km}$ dans les trois directions) et se caractérise de la manière suivante : d'une part, une sismicité de fond sous le golfe de Corinthe même; d'autre part, plusieurs essaims de sismicité, dont le plus important est associé à un séisme de magnitude $M w=4,2$, situé à $6 \mathrm{~km}$ au sud d'Aigion. L'activité sismique est confinée entre 4,5 et $11 \mathrm{~km}$ de profondeur. Les quatre premiers kilomètres de la croûte sont asismiques, et la profondeur des séismes augmente vers le nord. Cette sismicité n'est pas clairement reliée aux failles actives connues affleurant en surface. Elle définit plutôt une zone de déformation entre 6 et $10 \mathrm{~km}$ de profondeur, sur laquelle pourraient se brancher les failles normales actives. L'étude des répliques du séisme du 8 avril $2001(M w=4,2)$ associées au mécanisme au foyer de ce séisme, montre qu'il s'est produit à $6 \mathrm{~km}$ de profondeur sur un plan de faille orienté $\sim \mathrm{SW}-$ $\mathrm{NE}$, plongeant vers le nord-ouest à $40^{\circ}$. Il s'agit d'un séisme en faille normale, avec une composante décrochante dextre, qui s'est probablement produit sur une ancienne structure réactivée dans le champ de contrainte actuel (extension $\sim \mathrm{N} 10^{\circ}$ ) et qui n'émerge pas en surface.

\section{Introduction}

In April 2000, a semi-permanent seismological network of 12 stations was installed in the Aigion area in order to monitor the microseismicity of the Corinth Rift Laboratory (CRL) area. This network (CRLN) is complementary to other existing network in the area (PATNET run by the University of Patras, CORNET and ATHNET run by the University of Athens) that record the seismicity down to Ml magnitude 2.5 or 3 . The primary objective of this network is to provide continuous monitoring of the seismicity and accurate locations of events down to magnitude 1 in order to constrain active structures at depth in this restricted area.

In this paper we briefly analyse 2 years of seismic activity (April 2000-December 2001) and present a detailed study of the seismic crisis $6 \mathrm{~km}$ south of Aigion, that started in February 2001 and culminated with a $M w=4.3$ event on April 08 .

\section{Seismotectonic framework}

The Corinth Rift has long been recognised to be one of the most seismically active area in Europe and a large amount of recent tectonic, geodetic and seismological observations have contributed to provide a fairly detailed seismotectonic framework (e.g., [1,2,5, $6,8,17])$. From east to west, most of the largest active faults outcropping on land are located on the southern edge of this asymmetric rift and dip $\sim 60^{\circ}$ to the north (Fig. 1). The deformation, as seen from GPS observations, is very localised. The extension is $\sim \mathrm{N} 10^{\circ}$ and its rate varies from less than $1 \mathrm{~cm} \mathrm{yr}^{-1}$ in the east to $\sim 1.5 \mathrm{~cm} \mathrm{yr}^{-1}$ to the west in the Aigion area.

All large earthquakes (magnitude $>5.8$ ) occurring in the rift show almost pure normal faulting (Fig. 1) with a T-axis oriented $\sim \mathrm{N} 10^{\circ}$. In the eastern part of the rift, the 1981 Corinth earthquakes are clearly associated with major active faults observed at the surface (e.g., $[9,10])$. In the west around Aigion, although the Helike fault is known to be responsible for major destructive earthquakes (e.g., the $M s \sim 71861$ event [11, $13,14])$, the two most recent largest earthquakes in the Aigion area, the $M s=5.8$ Galaxidi event of 8 November 1992 [7] and the $M s=6.2$ Aigion event of 15 June 


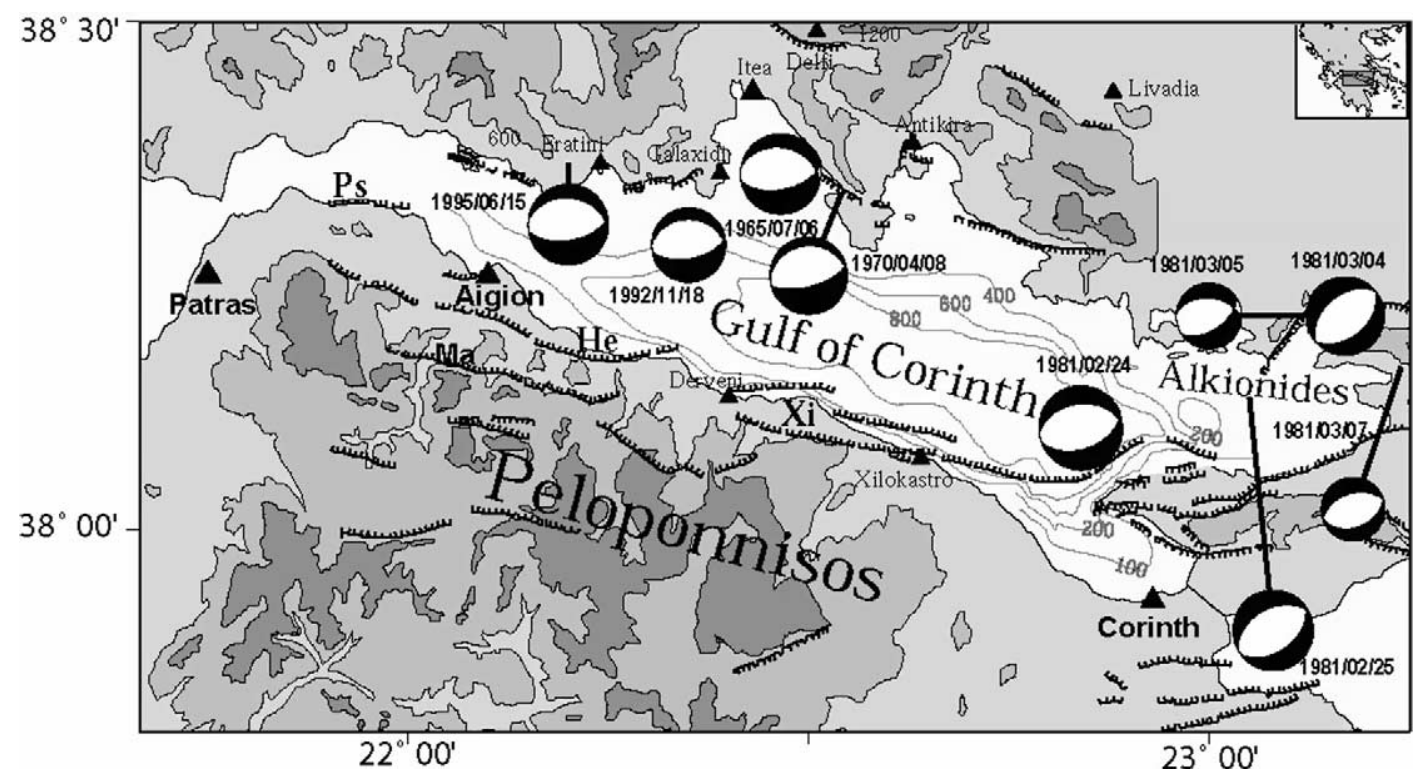

Fig. 1. Seismotectonic map of the Corinth Rift. Fault-plane solutions of events with magnitude larger than 5.8 since 1960 are taken from [3,4,7].

Fig. 1. Carte sismotectonique du rift de Corinthe. Les mécanismes au foyer des événements d'une magnitude supérieure à 5,8 depuis 1960 sont issues de $[3,4,7]$.

1995 [4] were not clearly associated with surface faulting. Both however indicate normal faulting on fairly low angle $\left(30-35^{\circ}\right)$ north-dipping fault planes.

The microseismic activity in the Aigion-Patras area is very large and Rigo et al. [17], based on the results of a two months recording experiment, proposed that the microseismicity concentrates at depths between 6 and $11 \mathrm{~km}$ in places where major steeply dipping faults observed at the surface seem to root on a more or less horizontal shear deformation zone. Relocation of few multiplets [16] indicated that some events may represent normal slip on very shallow planes $\left(\sim 15^{\circ}\right)$ in this shear zone. Alternatively, Hatzfeld et al. [8] interpreted this seismicity as the expression of the ductile-transition zone without any peculiar structure.

At present it is not easy to reconcile the various observations described above in a consistent scheme. Part of the reason is that some conclusions are being drawn from local observations over short periods of time that may or may not be representative of a large-scale process. Continuous observation of the seismicity with the Corinth Rift Laboratory Network should then help to obtain over time a clearer view of the active structures at depth.

\section{The Corinth Rift Laboratory seismological network}

The network is made up of seven stations installed on the southern coast of the gulf and of 5 stations on the northern coast (Fig. 2). Because we wanted to be able to monitor small magnitude events, we installed the velocimeters from the seven southern stations in 60-130-m deep boreholes in order to avoid very soft soils and human activity noise, which is quite large in the Aigion plain. However, only at AIO station could we succeed in installing the seismometer directly on the limestone. The borehole seismometers were installed in two steps, four stations in April 2000 (ALI, TEM, KOU and AIO) and three additional ones in March 2001 (AGE, DIM and ELE). The limestone is directly exposed on the northern side and some velocimeters are burried in shallow 2-m-deep holes. Seismometers have a velocity response peaked at a natural frequency of $2 \mathrm{~Hz}$. The signal, sampled at 125 points per second, is recorded continuously by TITAN3NT recorders. Data are stored on site and regularly gathered and sent to IPGP in Paris and to NUA in Athens. 

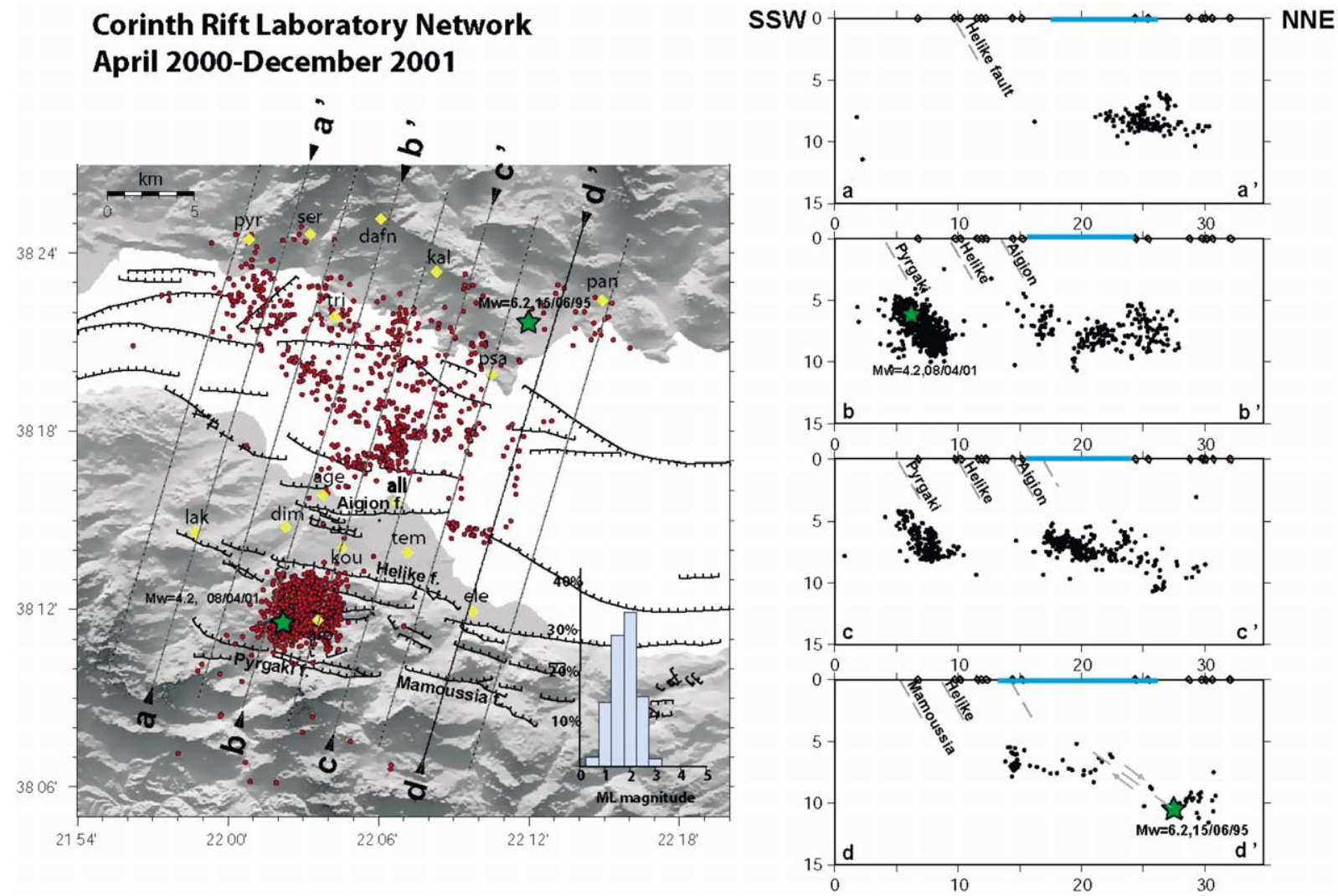

Fig. 2. Left: map of the CRLN seismological network (stations in yellow), including events located by the network from April 2000 to December 2001. All events plotted are located using at least $5 \mathrm{P}$ and $4 \mathrm{~S}$ arrivals, have a rms $<0.1 \mathrm{~s}$ and standard errors in latitude, longitude and depth smaller than $1 \mathrm{~km}$. Active faults in the Aigion area are from [14], offshore faults from [15]. Distribution of $M l$ magnitudes is shown on the right corner. Right: vertical cross-sections as indicated on the map. Major normal faults are indicated on cross-sections.

Fig. 2. À gauche : carte du réseau sismologique CRLN (stations en jaune), incluant des événements localisés par celui-ci entre avril 2000 et décembre 2001. Tous les événements représentés ont été localisés en utilisant au moins les arrivées $5 \mathrm{P}$ et $4 \mathrm{~S}$, ont un rms $<0.1 \mathrm{~s}$ et des erreurs standard en latitude, longitude et profondeur inférieures à $1 \mathrm{~km}$. Les données relatives aux failles actives dans la région d'Aigion sont issues de [14], celles relatives aux failles offshore de [15]. La distribution des magnitudes $M l$ est donnée dans le coin droit. À droite : coupes verticales selon les plans dessinés sur la carte. Les failles normales majeures sont indiquées sur les coupes.

These 12 stations are complemented by two stations from ATHNET run by the University of Athens (LAK and DAP). We also integrate in our dataset observations made at one station (SER) by the Prague University in collaboration with the Patras University. Overall, the Aigion area is fairly well covered although one station closing the network to the west on the southern coast would be useful.

From April 2000 to December 2001, over 6000 earthquakes were recorded by a mean of eight stations and located within the network. We use the 1D velocity model from Rigo et al. [17] to locate the earthquakes. About 2000 events were located with at least $5 \mathrm{P}$ and $4 \mathrm{~S}$ phase readings, standard location errors smaller than $1 \mathrm{~km}$ in all directions and rms smaller than $0.1 \mathrm{~s}$ (Fig. 2). Various tests, including velocity structure perturbations and initial depth and location perturbations have been performed. They indicate that the combination of the above criteria leads to stable locations with errors less than $1 \mathrm{~km}$ in all directions for events inside the network. Errors could be larger (up to $2 \mathrm{~km}$ ) for events of 8 April 2001 swarm when observations at AIO are not present. 


\section{Seismic activity}

Fig. 2 shows the best-located events recorded from April 2000 to December 2001. Seismicity is mainly concentrated inside the gulf itself with the exception of the swarm activity associated with the $M w=4.2$ event south of Aigion. For comparison, seismicity recorded during two months in 1991 [8,17] is shown on Fig. 3.

As in 1991, most events are located at depth between 4.5 and $11 \mathrm{~km}$ confirming that the seismogenic layer is very thin [17]. This is also consistent with the initiation depth of large earthquakes such as the 1992 Galaxidi and the 1995 Aigion earthquakes being at $\sim 10 \mathrm{~km}[4,7]$.

The upper part of the crust is aseismic. The number of seismic stations in the area of the Aigion and Helike fault is large enough to be able to detect any small shallow activity. During the two-year period studied here, only five events have been located at depth shallower than $4.5 \mathrm{~km}$. A similar observation was made in 1991 but at the time it was not clear whether this was an artefact from the network configuration or not. Even after the 8 April 2001 event that occurred at $5.5 \mathrm{~km}$ depth, no activity above $4.5 \mathrm{~km}$ was observed. For the Helike and the Aigion faults this observation is consistent with the fact that these faults appear to be locked from GPS and interferometry studies [2,5]. The lack of shallow activity under the gulf itself, although less well resolved than on shore, is more surprising. Given the very large strain rate in the gulf itself that needs to be accommodated in part by some kind of shallow creep [4], one would expect some shallow seismicity there.

The seismicity deepens towards the north and defines a zone of deformation including some cluster activity at $6-10 \mathrm{~km}$ depth on which large normal faults could branch. Comparison of Figs. 2 and 3 shows that these clusters move around with time. It also indicates that CRLN has a better resolution for events located below the gulf, due to the station density close to the
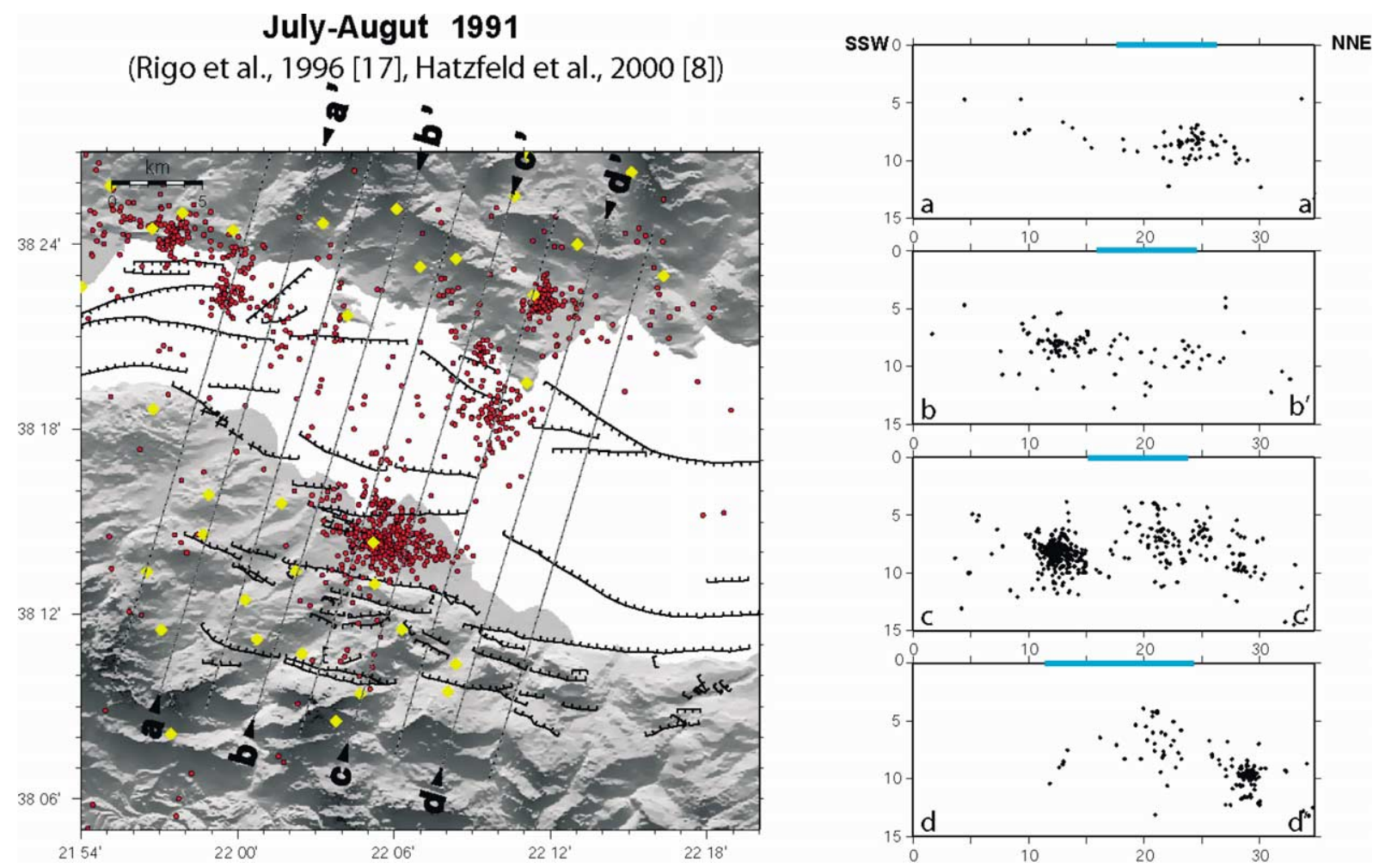

Fig. 3. Same as Fig. 2 for the seismicity recorded in July-August 1991 [8,17].

Fig. 3. Idem Fig. 2, pour la sismicité enregistrée en juillet-août 1991 [8,17]. 


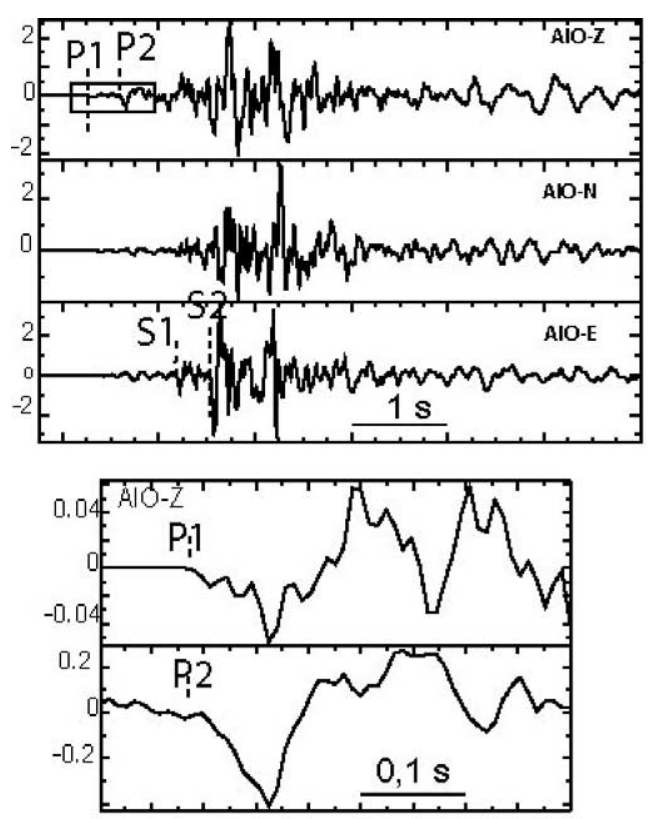

(a)
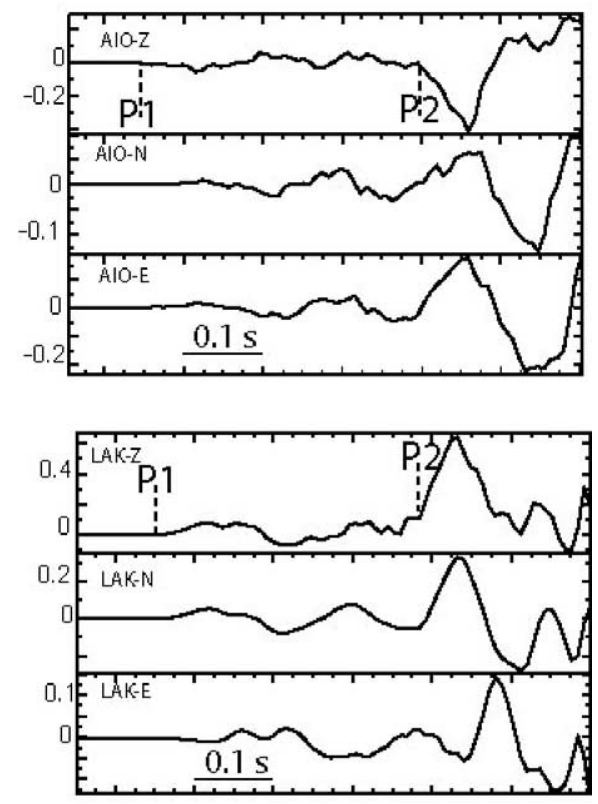

(b)

Fig. 4. (a) Waveforms recorded at AIO for the $M w=4.2,8$ April 2001 event, with a zoom on P1 and P2 arrivals. (b) Comparison of the P phases (P1 and P2) at AIO and LAK. Note that timing and amplitude ratio of P1 and P2 are similar at these two stations.

Fig. 4. (a) Formes d'onde enregistrées à AIO pour l'événement de magnitude 4,2 du 8 avril 2001, avec un zoom sur les arrivées P1 et P2. (b) Comparaison des phases P (P1 et P2) à AIO et LAK. Remarquer que les temps d'arrivée et les rapports d'amplitude de P1 et P2 sont similaires pour ces deux stations.

gulf border. It is however difficult to know how this seismicity relates to the main faults observed at the surface. More detailed studies of this seismicity (e.g., very precise locations using multiplets analysis) are necessary to try to answer this question. This work in progress [12] will be presented elsewhere. We will focus here on the swarm of seismic activity that lasted for more than 6 months, $\sim 6 \mathrm{~km}$ south of the city of Aigion.

\section{The 2001 swarm and the $M w=4.2,8$ April 2001 event}

The activity began slowly in February 2001, accelerated on 25 March and culminated on 8 April with the $M w=4.2$ event at $06: 12$ [19]. The activity was then high for about three months and slowly decayed.

\subsection{Location}

Although this swarm is located somewhat on the edge of our network, the presence of AIO station just above the swarm activity allows us to have a large amount of well-located events (errors $<1 \mathrm{~km}$ ). In particular the depths of events are well constrained by the $\mathrm{S}-\mathrm{P}$ arrival times at AIO. A difficulty however arises for the location of the main event that was recorded by eight stations, due to the complexity of the seismic signal recorded (Fig. 4). As can be seen on AIO and LAK recordings shown, two clear $\mathrm{P}$ arrivals (denoted $\mathrm{P} 1$ and P2) can be detected, separated by $\sim 0.35 \mathrm{~s}$. P2 has an amplitude 6 to 7 times larger than P1, but is very similar in waveform. P1 and P2 can fairly well be associated with S1 and S2 phases shown on AIO recording. P1 and P2 are also seen on other stations, but less clearly, as they are further away from hypocenter. The time separation between these two phases is less clearly measurable but is always between 0.3 and 0.4 s. Originally, as it was the P1 and S2 phases (the two best visible phases on the records) that had been picked for locating this event, the location (green star in Fig. 5) fell outside the foreshocks and aftershocks' cloud. Taking P2 and S2 phases, the new location 


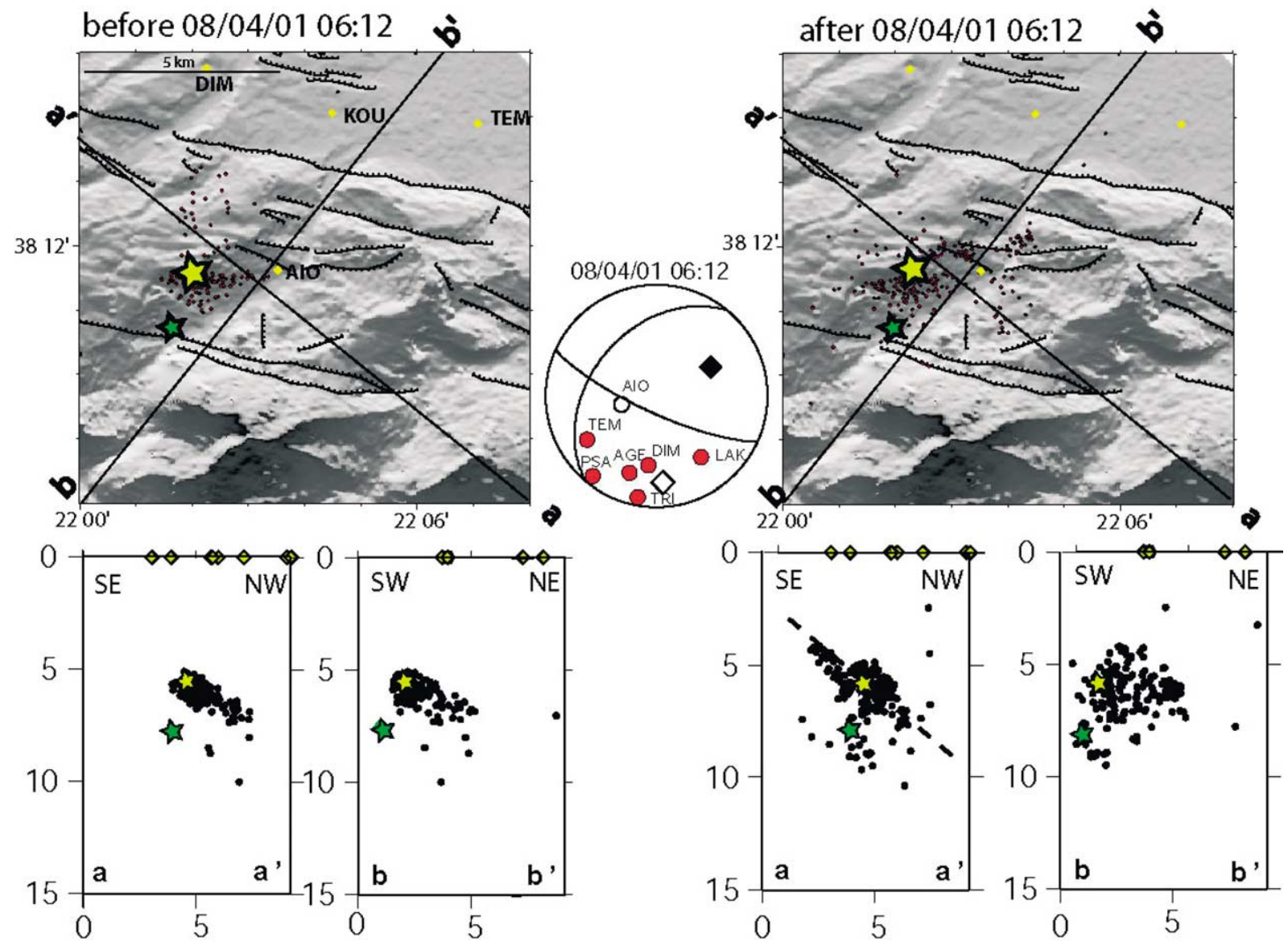

Fig. 5. Foreshocks and aftershocks of the 8 April 2001 event located by at least $5 \mathrm{P}$ and 4 S phases (including AIO station), with rms $<0.1 \mathrm{~s}$ and standard errors in latitude, longitude and depth less than $1 \mathrm{~km}$. Fault plane solution with polarities observed at CRLN stations is from Zahradnik et al. [19]. Open (black) square indicate T (P) axis. The green star indicates original mainshock location and the yellow one revised location (see discussion in the text). Dashed line on vertical cross-section indicates N220, $40^{\circ} \mathrm{NW}$ dipping fault plan.

Fig. 5. Précurseurs et répliques de l'événement du 8 avril 2001, localisé avec au moins 5P et 4S (y compris la station AIO), avec rms < 0.1 s et des erreurs standard en latitude, longitude et profondeur inférieures à $1 \mathrm{~km}$. Les mécanismes au foyer avec les polarités observées aux stations CRLN est issue de Zahradnik et al. [19]. Les carrés évidés (noirs) indiquent l'axe T (P). L'astérisque verte indique la localisation initiale du choc principal et l'astérisque jaune la localisation révisée (voir la discussion dans le texte). La ligne en tiretés sur la coupe verticale indique un plan de faille orienté $\mathrm{N} 220^{\circ}$, plongeant vers le nord-ouest à $40^{\circ}$.

$(\mathrm{rms}=0.06 \mathrm{~s})$ is shown with the yellow star and falls in the middle of the events' cloud.

\subsection{Active fault plane}

Fig. 5 shows best-located foreshocks and aftershocks for the whole swarm. In addition to selection criteria retained for Fig. 4, only events for which AIO phases were available have been used, which insures errors less than $1 \mathrm{~km}$ in the three directions. Fore- shocks are concentrated in space, in an area $\sim 2 \mathrm{~km} \times$ $2 \mathrm{~km}$, somewhat larger than the expected rupture area for the main event $(1 \mathrm{~km} \times 1 \mathrm{~km})$. Aftershocks are more dispersed, but have a clear spatial distribution: they align well on a SW-NE plane dipping $\sim 40^{\circ}$ to the northwest; on the contrary, no well-defined plane appears on north-south cross-sections. Aftershocks extend over about $5 \mathrm{~km}$ along this plane, from depths of $\sim 4.5 \mathrm{~km}$ to $7.5 \mathrm{~km}$, the mainshock being located more or less in the middle of this activated zone. This 
plane is in agreement with the preferred fault plane solution of the 8 April 2001 event obtained by Zahradnik et al. [19] from inversion of amplitude spectra of close broad band stations ( strike $=220^{\circ}$, dip $=40^{\circ}$, slip $=-160^{\circ}$ ). This fault plane solution is shown in Fig. 5, along with observed polarities of CRLN stations. The agreement of our observations with Zahradnik et al.'s results, strongly suggests that the fault responsible for the 8 April $2001 M w=4.2$ event is a SW-NE oriented fault, dipping $40^{\circ}$ to the northwest. Slip on this fault is oblique, with a normal and a right lateral component.

Such a faulting is rather surprising in a context where all major active faults have azimuths of $\sim 100^{\circ}$ and dip to the north. In fact, the 8 April fault cannot be associated with any faults mapped at the surface. If extended up to the surface, this fault plane should intersect the Pirgaki fault. During the swarm activity, there is no evidence that the seismicity spreads out and branches on the Pirgaki fault. It looks as if these two faults were somewhat decoupled one from each other, which could indicate that the Pirgaki fault is rather shallow and does not reach deeper than about $5 \mathrm{~km}$, as suggested by Sorel [18].

Although surprising, this fault plane solution indicates an almost horizontal $\mathrm{T}$ axis oriented $\mathrm{N} 176^{\circ}$, which is very consistent with the overall state of stress of the area. One possibility is that this event is associated with the reactivation of an older structure in the present stress field. The azimuth of the fault plane is close to the main direction of the Hellenides and the earthquake may have reactivated some old thrust active at the time of the Hellenides formation. Alternatively, this event could be interpreted as a transfer faulting between the Helike and the Mamoussia fault, although no geological evidence of such a faulting exists.

\section{Conclusions}

The image of the seismicity recorded in the Aigion area during the two-year activity of CRLN is bimodal: a background seismicity within the Corinth gulf and an earthquake swarm $6 \mathrm{~km}$ south of Aigion. In both cases, the seismicity is not directly associated with major known active faults that can be mapped at the surface. Most of the seismicity occurring inside the gulf is at a depth between 6 and $10 \mathrm{~km}$, slightly deepening towards the north; no earthquake occurs in the upper $4 \mathrm{~km}$ of the crust. The detailed analysis of the swarm associated with the $M w=4.2$ event shows that it is associated with a SW-NE oriented fault dipping $40^{\circ}$ to the northwest. Such activity, rather unexpected in the present-day tectonic context of the area, is important to document. In this context, the dense dataset provided by CRLN provides useful recordings of moderatesized events such as the ones studied. These events may be used to map active faults in detail, whether or not they happen to break the surface.

\section{Acknowledgements}

The CRLN equipment was funded by INSU-CNRS in France. We would like to thank F. Cornet for his very important input in the installation phase of the borehole seismometers. We also thank D. Brunel, H. Castarède, C. Deléglise, G. Oganecian, J. Sellier, and R. Verhille for their help at various stages in the installation of the network. Maintenance of the network by N. Germinis and C. Skarpelos has been possible through EC environment program, seismic hazard, CORSEIS contract EVG1-CT99-00002 and through GDR-Corinthe. Part of the data analysis presented here was done under EC CORSEIS contract and IST program, AEGIS contract IST-2000-26450. We are grateful to J. Zahradnik for letting us use the data from SER station and for stimulating discussions.

We thank I. Main and D. Hatzfeld for reviewing the manuscript.

\section{References}

[1] R. Armijo, B. Meyer, G. King, A. Rigo, D. Papanastassiou, Quaternary evolution of the Corinth Rift and its implications for the Late Cenozoic evolution of the Aegean, Geophys. J. Int. 126 (1996) 11-53.

[2] A. Avallone, P. Briole, A.M. Agatza-Balodimou, H. Billiris, O. Charade, C. Mitsakaki, A. Nercessian, K. Papazissi, D. Paradissis, G. Veis, Analysis of eleven years of deformation measured by GPS in the Corinth Rift Laboratory area, C. R. Geoscience 336 (2004) 301-311, this issue.

[3] C. Baker, D. Hatzfeld, H. Lyon-Caen, E. Papadimitriou, A. Rigo, Earthquake mechanisms of the Adriatic Sea and western 
Greece: implications for the oceanic subduction-continental collision transition, Geophys. J. Int. 131 (1997) 559-594.

[4] P. Bernard, P. Briole, B. Meyer, H. Lyon-Caen, J.-M. Gomez, C. Tiberi, C. Berge, R. Cattin, D. Hatzfeld, C. Lachet, B. Lebrun, A. Deschamps, F. Courboulex, C. Laroque, A. Rigo, D. Massonnet, P. Papadimitriou, J. Kassaras, D. Diagourtas, K. Makropoulos, G. Veis, E. Papazisi, C. Mitsakaki, V. Karakostas, E. Papadimitriou, D. Papanastassiou, G. Chouliaras, G. Stavrakakis, The $M s=6.2$, June 15, 1995 Aigion Earthquake (Greece): evidence for low angle normal faulting in the Corinth Rift, J. Seismol. 1 (1997) 131-150.

[5] P. Briole, A. Rigo, H. Lyon-Caen, J.C. Ruegg, K. Papazissi, C. Mitsakaki, A. Balodimou, G. Veis, D. Hatzfeld, A. Deschamps, Active deformation of the Corinth Rift, Greece: results from repeated Global: Positioning System surveys between 1990 and 1995, J. Geophys. Res. 105 (2000) 2560525625.

[6] P.J. Clarke, et al., Geodetic estimation of seismic hazard in the Gulf of Corinth, Geophys. Res. Lett. 24 (1997) 1303-1306.

[7] D. Hatzfeld, D. Kementzetzidou, V. Karakostas, M. Ziazia, S. Nothard, D. Diagourtas, A. Deschamps, G. Karakaisis, P. Papadimitriou, M. Scordilis, R. Smith, N. Voulgaris, S. Kiratzi, K. Makropoulos, M.P. Bouin, P. Bernard, The Galaxidi earthquake of 18 November 1992: a possible asperity within the normal fault system of the Gulf of Corinth (Greece), Bull. Seismol. Soc. Am. 86 (1996) 1987-1991.

[8] D. Hatzfeld, V. Karakostas, M. Ziazia, I. Kassaras, E. Papadimitriou, K. Makropoulos, N. Voulgaris, C. Papaioannou, Microseismicity and faulting geometry in the Gulf of Corinth (Greece), Geophys. J. Int. 141 (2000) 438-456.

[9] A. Hubert, G. King, R. Armijo, B. Meyer, D. Papanastassiou, Fault reactivation, stress interaction and rupture propagation of the 1981 Corinth earthquake sequence, Earth Planet. Sci. Lett. 142 (1996) 573-585.

[10] J. Jackson, et al., Seismicity, normal faulting and the geomorphological development of the Gulf of Corinth (Greece): the Corinth earthquakes of February and March 1981, Earth Planet. Sci. Lett. 57 (1982) 377-397.

[11] N. Mouyaris, D. Papastamatiou, C. Vita-Finzi, The Helice Fault, Terra Nova 4 (1992) 124-129.

[12] F. Pacchiani, H. Lyon-Caen, S. Bourouis, P. Bernard, A. Deschamps, P. Papdimitriou, K. Makropoulos, Relocation of the microseismicity in the Corinth Rift and implications on the faulting geometry, EGU, April 2003.

[13] D. Pantosti, M. De Martini, I. Koukouvelas, L. Stamatopoulos, S. Pavlides, N. Palyvos, S. Pucci, F. Lemeille, Palaeoseismological trenching across the Aigion Faults (Gulf of Corinth, Greece), C.R. Geoscience 336 (2004) 335-342, this issue.

[14] D. Pantosti, N. Palyvos (Eds.), Eliki and Aigion fault GIS data base, E.C. Corseis project, http://www.ingv.it/ wwwpaleo/ pantosti/aigion/database.

[15] D. Papanikolaou, M. Alexandri, P. Nomikou, D. Ballas, Morphotectonic structure of the western part of the North Aegean Basin based on swath bathymetry, Mar. Geol. 190 (2002) 465492.

[16] A. Rietbrock, C. Tiberi, F. Scherbaum, H. Lyon-Caen, Seismic slip on a low-angle normal fault in the Gulf of Corinth: evidence from high resolution cluster analysis of microearthquakes, Geophys. Res. Lett. 14 (1996) 1817-1820.

[17] A. Rigo, H. Lyon-Caen, R. Armijo, A. Deschamps, D. Hatzfeld, K. Makropoulos, P. Papadimitriou, I. Kassaras, A microseismic study in the western part of the Gulf of Corinth (Greece): implications for large scale normal faulting mechanisms, Geophys. J. Int. 126 (1996) 663-688.

[18] D. Sorel, A Pleistocene and still-active detachment fault and the origin of the Corinth-Patras rift, Greece, Geology 28 (2000) 83-86.

[19] J. Zahradnik, J. Jansky, E. Sokos, A. Serpetsidaki, H. LyonCaen, P. Papadimitriou, Modeling the $M_{\mathrm{L}}=4.7$ mainshock of the February-July 2001 earthquake sequence in Aigion, Greece, J. Seismol. (in press). 